\title{
HER2/Neu Positive by Immunohistochemistry 11-20 Percent
}

National Cancer Institute

\section{Source}

National Cancer Institute. HER2/Neu Positive by Immunohistochemistry 11-20 Percent. NCI Thesaurus. Code C141495.

An immunohistochemical staining finding indicating that 11-20 percent of the cells in a tissue sample are expressing receptor tyrosine-protein kinase erbB-2. 